PAWEE WYBORSKI

\title{
TOWARZYSKOŚĆ W BUTELCE - WINO W RELACJACH SPOŁECZNYCH
}

\begin{abstract}
Wyborski Paweł, Towarzyskość w butelce - wino w relacjach spotecznych [Sociability in a bottle - wine in social relations] edited by M. Krajewski - „Człowiek i Społeczeństwo", vol. XXXIII, Poznań 2012, pp. 41-64. Adam Mickiewicz University Press. ISBN 978-83-232-2484-6. ISSN 0239-3271.

The purpose of this article based on in-depth interviews with Polish wine consumers/amateurs is to consider whether wine consumption may be perceived as an agent of social relations. I argue that collective wine drinking occasions may be sociologically understood as exemplifications both of Simmelian idea of sociability and Maffesoli's modern tribalism. Consequently the main problem of the text is also to stress the role of social context in experiencing consumption pleasures as well as the significance of sharing common standards of taste in constructing and maintaining social relations

Paweł Wyborski, Wyższa Szkoła Społeczno-Ekonomiczna w Gdańsku, ul. Łagiewniki 3, 80-847 Gdańsk, Poland.
\end{abstract}

\section{UWAGI WSTĘPNE}

Zamierzeniem tekstu jest przyjrzenie się pewnemu wymiarowi czy też możliwym konsekwencjom konsumpcji wina, zawierającym się w odpowiedzi na pytanie: jak mogą zmieniać się - i w jakim kierunku - społeczne relacje jednostek uwikłanych $\mathrm{w}$ fenomen spożywania trunku. Czy wino, jak i praktyki jego konsumowania można traktować jako mechanizm tworzący i podtrzymujący społeczne więzi miedzy jednostkami? Jakie wzory konsumowania pociągać może za sobą specyfika tego napoju? Te przykładowe pytania stanowią pole problemowe tego artykułu, który jest próbą zastanowienia się nad pewnymi wybranymi rezultatami konsumpcji, ale dokonywanymi, by powiedzieć za Ianem Woodwardem (2001: 117), z perspektywy konsumowanego dobra (wina), używanego, uruchamianego i współdzielonego przez aktorów społecznych. Przyjmuję zatem, w pewnym uproszczeniu, w ślad za badaczami socjologicznego znaczenia przedmiotów (Krajewski 2008; Woodward 2001; Watson 2008), że akty spożywania 
trunku można rozumieć jako przypadki nawiązywania i utrzymywania $\mathrm{z}$ nim relacji przez jego amatorów ${ }^{1}$.

Bohaterem niniejszego szkicu jest wino i jego szczególna zdolność polegająca na łączeniu ludzi ze sobą $\mathrm{w}$ ramach sytuacji jego spożywania, a $\mathrm{w}$ konsekwencji - zakładania i regulowania relacji społecznych. Tematem tekstu będzie społeczny charakter konsumpcji napoju, który konsumowany bywa zazwyczaj wśród innych ludzi, jednak formy i natężenie obecności innych osób mogą przybierać różne formy. Zastrzegam jednakże, że pod uwagę $\mathrm{w}$ tym artykule brać będę wyłącznie sytuacje spożywania wina, a nie np. jego pozyskiwania (kupowania), choć same w sobie stanowią one także interesujące pole wyłaniania się specyficznych społecznych relacji. Rozważania oparte są na materiale empirycznym pochodzącym z wywiadów pogłębionych ${ }^{2}$ zrealizowanych $\mathrm{z}$ konsumentami wina na różnym stopniu zaawansowania, o zróżnicowanych zasobach wiedzy o nim. Kierując się troską o jak najwierniejsze odtworzenie refleksji badanych, postaram się uwypuklić różne aspekty społecznych form konsumowania wina, na które zwracają uwagę informatorzy. Podkreślam jednak, że zaprezentowane możliwości stanowią jedynie punkt wyjścia, który sygnalizuje interesującą przestrzeń badawczą, a tym samym konieczność dalszego eksplorowania problemu ${ }^{3}$.

Jak zauważył Tim Dant (2005: 25), socjologiczno-antropologiczne rozważania nad konsumpcją i rolą przedmiotów zwykle pomijały kwestię, w jaki sposób żyje się z rzeczami, jak są one przeżywane i w jaki sposób ich właściwości prowadzą do określonych działań. Artykuł jest zatem próbą wpisania się w zgłaszany przez brytyjskiego socjologa problem, a zarazem

\footnotetext{
${ }^{1} \mathrm{~W}$ tekście, wymiennie ze słowem „konsument”, używam pojęcia „amator” na oznaczenie osób lubiących i spożywających wino, zgodnie ze znaczeniem, jakie nadał mu Antoine Hennion (2008:112). „Amator” oznaczać ma osoby z entuzjazmem i zaangażowaniem wobec jakiejś sfery aktywności czy dobra i ma w związku z tym inny wydźwięk niż „koneser”, który kojarzy się bardziej ekspercko i profesjonalnie.

2 Wywiady dotyczyły roli i znaczenia, jakie posiada wino (i jego spożywanie) w życiu badanych osób, a dyspozycje do wywiadów obejmowały m.in. okoliczności spożywania, preferowane wzory konsumpcji, udział innych osób w sytuacjach konsumpcji, popularność wina we współczesnej Polsce, możliwe konsekwencje zainteresowania winem oraz motywy zainteresowania się trunkiem. W okresie od czerwca 2010 do stycznia 2011 zrealizowanych zostało osiem wywiadów (Trójmiasto i okolice), które pozwoliły na uchwycenie kluczowych wątków związanych z wpływem wina na swoich konsumentów, które stanowić będą przedmiot dalszych badań.

${ }^{3}$ Jest oczywiste, że rozmiar zebranego materiału empirycznego nie pozwala na wysnuwanie daleko idących wniosków, dlatego też zastrzegam, że niniejszy tekst stanowi raczej zaproszenie do wglądu w ciekawą przestrzeń problemową, jaka rysuje się w ramach analizy więziotwórczych potencji wina. Formułowane $\mathrm{w}$ nim uwagi stanowią $\mathrm{w}$ tym sensie tylko i wyłącznie sygnał oraz zachętę do dalszych badań, a nie wyczerpany katalog możliwych rozwiązań.
} 
odnosi się, na przykładzie wina, do jednego z fundamentalnych aspektów socjologicznej refleksji nad związkami ludzi i przedmiotów - aktywnej i dynamicznej roli rzeczy w zakładaniu i podtrzymywaniu społecznych relacji (Douglas, Isherwood 1996: 39; Komter 2001: 73; Dant 2007: 14). Głównym zamierzeniem szkicu będzie nakreślenie kilku, wyłaniających się z badań empirycznych, możliwych rezultatów spożywania wina - zróżnicowanych związków międzyludzkich, jakie stają się udziałem konsumentów wina.

Antheleme Brillat-Savarin określał wino jako nieodłączny i najbardziej zwyczajowy składnik posiłku, którego obecność w ramach aktu jedzenia nie podlega żadnym wątpliwościom. Jak zauważył Roland Barthes (2000), spożywanie tego napoju jest nie tylko niewątpliwym gestem ozdobnym, ale także "trwaniem aktu picia”, a zatem specyficzną przestrzenią (okolicznością), w której rozgrywa się zaaranżowany akt konsumpcji trunku. Nietrudno dostrzec, że taka specyficznie wydzielona przestrzeń obejmować musi również innych ludzi, którzy stają się towarzyszami w konsumpcji, a zarazem osobami znaczącymi, którzy współuczestniczą (ale i współtworzą) doświadczenie konsumpcji wina. Jakkolwiek Georg Simmel (2006) w swojej socjologicznej wizji posiłku, nie wspominał o obecności trunku, to jednak bez większego wysiłku można wyobrazić sobie wino jako zarówno możliwy czynnik strukturyzujący i stylizujący formę spożywania, jak i element wprzężony w społecznie ustalony porządek określający sytuację jedzenia (por. Wyborski 2011).

Problematyka spożywania alkoholu, w którym odbijają się społeczne normy i wartości, tradycje i historie, otwiera okno, przez które można zyskać dostęp do innych poziomów i czynności kulturowych społeczeństwa. Picie samo $\mathrm{w}$ sobie ma charakter kulturowy $\mathrm{i}$ jak w zwierciadle przeglądają się w nim instytucje oraz wartości określonej kultury (Douglas, Isherwood 1996: 50; Wilson 2005: 3-4). Według Mary Douglas (1987: 8-12), w napojach alkoholowych i sposobach ich konsumowania odbija się natura społecznego świata - zarówno w sensie realnej konstytucji rzeczywistości społecznej, jak i przekonań co do jej struktury idealnej. Refleksja nad czynnościami spożywania różnych produktów alkoholowych jest w tym sensie jak najbardziej miarodajną sposobnością wglądu w kształt życia społecznego. W ten sam sposób degustowanie wina, choćby najbardziej niezwykłego, nie odsyła jedynie do rejestru smakowo-zapachowych wzruszeń, jakie mogą stać się udziałem amatorów, ale przede wszystkim - do społeczno-kulturowych kategorii, które kwalifikują oraz regulują takie zdarzenia i wrażenia z nimi powiązane.

Rozważając problem możliwych konsekwencji praktyk konsumowania wina, należy zwrócić uwagę na odnotowywane w literaturze przedmiotu 
zjawisko tzw. „nowej kultury wina”4 (Demossier 2005; 2010: 70-100), czyli, inaczej mówiąc, ogromnej kariery, jaka stała się udziałem trunku w ostatnich kilku dziesięcioleciach. Spożycie wina zdemokratyzowało się, obejmując coraz szersze kategorie społeczne, a refleksem zmian stała się wzrastająca widzialność i popularność konsumpcji wina, jak i rozkwit specjalistycznych wydawnictw, magazynów, przedmiotów czy miejsc poświęconych spożywaniu trunku. Specyficznym przejawem popularności wina jest także pojawienie się w ostatnich latach coraz liczniejszej grupy "nowych konsumentów" w społeczeństwach dotychczas postrzeganych jako zorientowane głównie na konsumpcję piwa lub mocniejszych napojów, jak i systematyczny trend wzrostowy spożycia wina w tych krajach (np. w Polsce - Resnick 2008). Jak zauważa Marion Demossier (2005; 2010), typowym wzorem osobowym właściwym „nowej kulturze wina” okazuje się postać „winiarskiego wędrowca" - amatora na różnych poziomach zaawansowania, a zarazem poszukiwacza doświadczeń oraz reżysera własnego stylu życia. Współcześnie wino uzyskuje zatem status coraz bardziej pożądanego dobra konsumpcyjnego, dostrajając się tym samym do oczekiwań współczesnego konsumenta, zorientowanego na realizowanie strategii estetyzacyjnych wyznaczanych przez politykę kształtowania stylu życia. Wino staje się zdemokratyzowanym i relatywnie dostępnym obiektem prestiżowym, wiążącym się z manifestacją dobrego smaku.

\section{CYWILIZUJACY POTENCJAŁ PRAKTYK KONSUMPCJI WINA}

Pomimo często formułowanych stwierdzeń przyznających winu specyficzne i odrębne miejsce pośród napojów alkoholowych (np. Barthes 2000; Colman 2008 :8-10), ze względu właśnie na obecność komponentu alkoholowego w napoju, konieczne jest jednak pewne istotne dopowiedzenie. Po pierwsze, cały tekst odnosi się wyłącznie do kategorii wina określanego w literaturze przedmiotu jako wino jakościowe (premium wine) ${ }^{5}$. Stanowi

4 Pierwsze symptomy "nowej kultury wina" datuje się na początki lat siedemdziesiątych XX wieku we Francji, jednak w ostatnich dziesięcioleciach popularność wina staje się już globalnym faktem kulturowym, obejmując kraje tradycyjnie winiarskie (np. Francja, Włochy), jak i te, które dotąd nie kojarzyły się z winem (np. Wyspy Brytyjskie, Skandynawia, Europa Środkowo-Wschodnia, Japonia czy Chiny) (Demossier 2010; Charters 2006; Resnick 2008).

${ }^{5}$ Należy podkreślić fakt ogromnego zróżnicowania wina. Przyjmuje się, że wino występuje $\mathrm{w}$ dwóch zasadniczych rodzajach, którym przypisuje się różne walory: wino jakościowe (premium wine), dostępne w butelkach określonej objętości (najczęściej 0,75 litra) oraz bulk wine (Charters 2006: 51-57). Bulk wine jest winem niskiej jakości, występującym zwykle w dużych objętościach, właściwym dla krajów rozwiniętych winiarsko i spożywanym najczęściej ze względu na zawartość alkoholu. W krajach niewiniarskich (czyli m.in. w Polsce) bulk wine 
ono ten rodzaj trunku, któremu w najmniejszym stopniu można przypisywać społecznie niepożądane rezultaty spożycia alkoholu (Charters 2006: 5157; 264). Po drugie, przyjmuję ponadto - kluczowe dla całości rozważań założenie o cywilizującym charakterze relacji z winem, które wiąże się zarówno z wyrafinowanym sposobem konsumpcji, jak i - przede wszystkim - z umiarkowanym spożyciem i raczej nacechowanym samokontrolą wzorem picia (Charters 2006: 176-204; Colman 2008: 8). Na mocy inspiracji Eliasowskim procesem cywilizującym oraz w zgodzie z przekonaniem, że dobra konsumpcyjne i przedmioty mogą być nośnikami takiego wpływu (Dant 2006), założyć można, że prospołeczny charakter konsumpcji wina, czyli taka właściwość relacji z nim, której efektem staje się otwieranie na innych ludzi i wprowadzanie amatorów w nowe związki społeczne, a w konsekwencji zagęszczanie sieci ludzkich relacji wokół jednostki (Elias 1990: 367-376; van Krieken 1998: 99-100; Mennell 2007: 17-18; Smith 2001: 21-22), jest jednym $\mathrm{z}$ istotnych wymiarów cywilizującego oddziaływania konsumpcji wina. Problematyka możliwych społecznych konstelacji narastających wokół fenomenu spożywania trunku wpisuje się zatem w szerszy problem cywilizowania poprzez wino.

Między innymi, oznacza to, że spotkanie przy winie nie będzie zawsze oznaczać alkoholowej libacji:

Wino ma w sobie to coś fajnego, że ono od razu ustawia człowieka na pewnym poziomie. I pewna jakość zachowania przy winie nie wypada i myślę, że wszystkie osoby, niezależnie czy piją to wino ze świadomością czy bez świadomości - ceny, jakości czy duszy włożonej w jego przygotowanie, wiedzą, że picie wina i konsumpcja alkoholu w postaci wina wymaga od nich pewnej jakości. To jest myślę fajne [...] Nie znam ludzi, poza, nie wiem, jakimś tam przypadkiem stoczniowców, związkowców Solidarności, którzy zamawiali wina po 500 zł w barze, żeby się upić, bo stwierdzili, że to będzie fajne. To jest akurat ten wyjątek, który potwierdza ta regułę (M/41/Gdańsk).

Dla mnie jest niepojęte upicie się winem, absolutnie. Wino jest zbyt szlachetnym trunkiem, żeby można było upijać się winem [...] Dla mnie wino to jest tak jak obcowanie, że tak powiem, z literaturą, dobrą literaturą [...] Ja sobie nie wyobrażam, żeby ktoś, mając lampkę wina, przeklinał. To jest tak samo, jak jest pan na jakimś wieczorze poezji, powiedzmy, no i ktoś by zaczął bluzgać, za przeproszeniem. No to jest tak samo, a nawet jeszcze bardziej. Nie wyobrażam sobie (M/56/Gdańsk).

Cywilizowany charakter trunku może także wynikać, na co zwraca uwagę kolejny informator, $\mathrm{z}$ woli amatora wina, aby świadomie i w pełni uczestni-

występuje w bardzo niewielkich ilościach, a analogicznych właściwości należy upatrywać raczej w tzw. winie owocowym, które oczywiście także nie jest przedmiotem rozważań tego artykułu. 
czyć wraz z innymi osobami w sytuacji konsumowania, czerpiąc z tych okoliczności możliwie najwięcej przyjemności.

Wino, które pijemy po prostu uczy nas jak się zachowywać. Nie wyobrażam sobie, żeby na degustacji wziąć, chlapnąć i czekać, kto szybciej doleje. Bo jak ktoś raz zobaczył coś, co go zachwyciło, to nie chce tego jakby spłaszczać, chce czerpać jak najbardziej szeroko, a to właśnie będąc razem w towarzystwie tym się cieszymy (M/51/Gdynia).

Konsumpcja wina wiązać może się także z zaproszeniem do jego poznawania (Demossier 2004: 96-97).

Wino to jest taki napój zagadka [...] I ta zagadka odnosi się do samego charakteru wina, do tego, że ono chce być w jakimś sensie rozgryzione, rozszyfrowane [...] Dla mnie wino przede wszystkim łączy się z pewnym poszukiwaniem, z poszukiwaniem wiedzy o winie, bo wino, wydaje mi się, że jak się człowiek poważnie zabierze za wino i jak człowiek w poważny sposób podejdzie do konsumpcji wina, to nie ma wyboru tylko powinien $\mathrm{w}$ to wino coraz bardziej wchodzić, powinien tym winem się zajmować nie tylko od strony picia. Właśnie to jest taka obustronna zależność, że im więcej chcę czerpać radości z picia wina, tym bardziej powinienem też stosunek do wina rozwijać poprzez sięganie np. do odpowiedniej literatury czy generalnie rzecz biorąc - uczenie się wina (M/36/Gdańsk).

Tim Crane (2007: 152) zauważa, że najbardziej dystynktywną cechą wina na tle pozostałych produktów kulinarnych jest fakt, iż skłania ono swoich konsumentów do podejmowania prób zrozumienia jego właściwości. Wino mobilizuje swoich amatorów do bycia świadomymi konsumentami. Stawia zadania i wymagania. Prowokuje do poszukiwania specjalistycznej wiedzy, poznawania kolejnych odmian czy ćwiczenia umiejętności rozpoznawania i odróżniania. To także wymiar cywilizowanego charakteru trunku (Charters 2006: 176-204), a jednocześnie możliwy warunek satysfakcjonującej relacji z winem.

\section{TŁO TEORETYCZNE ROZWAŻAŃ}

Według diagnozy Michela Maffesoliego (2008), którą przyjmuję w tekście jako trafną matrycę dla obserwowania związków opartych na konsumowaniu wina, specyfikę współczesnych form uspołecznienia odbija metafora uczuciowej mgławicy, czyli pewnej masy nieokreślonych kształtów, w której „krystalizują się zbiorowości wszelkiego rodzaju, punktowe, ulotne, o rozmytych konturach" (Maffesoli 2008: 116-117). Późnonowoczesna zbiorowa wrażliwość zorientowana jest przede wszystkim na uczucia i wrażenia. Dziedzina jedzenia i produktów kulinarnych stanowi natomiast 
jeden ze specyficznych obszarów, w których uaktywnia się ta szczególna społeczna aura, znaczona płynnością, rozproszeniem i tymczasowymi zrzeszeniami, słowem - kolejnymi "przypływami i odpływami plemion" (Maffesoli 2008: 122).

Emblematycznymi nośnikami tej zbiorowej wrażliwości są właśnie plemiona (nowoplemiona) ${ }^{6}$, przypisane zwykle strukturom wielkomiejskim, stanowiące "sieci przyjaźni, które nie mają żadnego celu poza gromadzeniem ludzi bez konkretnego zamiaru, bez określonego projektu, a które w coraz większym stopniu przenikają życie codzienne wielkich zbiorowości" (Maffesoli 2008: 53). Zainteresowanie winem, jak będzie to widać $\mathrm{w}$ dalszych wypowiedziach badanych, może stanowić doskonałe źródło i kontekst dla formowania się nowoplemion, a jednocześnie, należy zastrzec, nie wpisuje się $\mathrm{w}$ tym sensie $\mathrm{w}$ żaden program czy projekt, jaki takie grupy miałyby zamiar realizować. Pasja dla wina jest jedynie powodem do spotykania się i zanurzenia we „wspólnym przeżywaniu teraźniejszości” (Maffesoli 2008: 120).

Nowoplemiona w ujęciu Maffesoliego stanowią ważny mechanizm wyjaśniający zachowania współczesnego konsumenta, jak i umożliwiają rozumienie znaczenia stylizowanej konsumpcji w społeczeństwach późnej nowoczesności (Bennett 1999: 606-607; Warde 1997: 184-185). Jak dopowiada Alan Warde (1997), nowoplemię narzuca swym członkom pewien poziom dyscypliny w odniesieniu do kryteriów smaku i sądzenia. To właśnie estetyczne reguły stanowią o istnieniu takiej grupy i są dla jej funkcjonowania konstytutywne. Jest zatem niezmiernie ważne, aby dość restrykcyjnie egzekwować ich przestrzeganie. Plemię bywa zatem świadome swoich reguł. Członkowie mogą wycofać się w każdym momencie, ponieważ uczestnictwo ma charakter tymczasowy i warunkowy, jednakże tak długo jak dobrowolnie uczestniczą $\mathrm{w}$ zbiorowości, tak długo muszą być posłuszni wobec grupowych standardów. Zwykła wspólnota opiera się na znacznie bardziej luźnym trybie zasad, zwykle chętnie przestrzeganych, bo zwyczajowo wtopionych w strukturę grupy i przez to mniej dostrzegalnych (Warde 1997: 184-185).

Równolegle do Maffesoliego i w nawiązaniu do konceptu „wspólnot estetycznych" Scotta Lasha (Beck, Giddens, Lash 2009) Jukka Gronow (1997: 170-171) proponuje zbliżone, choć nieco szersze spojrzenie na problem społeczności kultywujących wspólne standardy smaku - koncepcję „wspólnot smaku". Wspólnoty smaku pozostają związkami luźnymi i opartymi jedynie na podobieństwie gustu i wcale nie muszą egzekwować posłuszeństwa wobec członków. Udział w nich wcale nie musi pociągać za sobą wspólnych

6 W tekście wolę używać pojęcia „nowoplemiona”, jako że podkreśla ono odrębny charakter tej formy uspołecznienia $\mathrm{w}$ porównaniu z tradycyjnie rozumianymi "plemionami”, pozostając w zgodzie z rozumieniem Maffesoliego (por. Bennett 1999: 606). 
znaczeń, praktyk czy zobowiązań. Charakterystyczny dla wspólnot smaku jest - rozumiany i inspirowany Simmlowską (2006) towarzyskością - mechanizm wzajemności, który sprawia, że indywidualne odczuwanie przyjemności splecione zostaje z radością wszystkich członków zgromadzenia. W warunkach społeczności opartych na podobieństwie gustów czy stylu życia standardy i kryteria smaku, opierające się na indywidualnych preferencjach, pozostają uzgodnione $\mathrm{w}$ formę wspólną wszystkim, zacierając fundamentalną różnicę między tym, co jednostkowe, a tym, co zbiorowe. Wspólnoty smaku, oparte na zmiennych standardach gustu, są formacjami niezwykle plastycznymi i zmiennymi, mimo wszystko jednak, jako ważny mechanizm uspołecznienia, spełniają coraz bardziej istotną rolę w konstytuowaniu porządku późnonowoczesnego społeczeństwa.

Na potrzeby tego artykułu przyjmuję, że obie zarysowane wyżej opcje przekładają się na dwie pokrewne wobec siebie możliwości socjologicznego rozumienia zbiorowości opartych na wspólnych preferencjach konsumpcyjnych. Zakładam w związku z tym możliwość wymiennego posługiwania się nimi w opisie form społecznych znaczonych wspólną konsumpcją wina. Szerokie ujęcie Gronowa kładzie nacisk na wspólnotę gustu, która niekoniecznie musi pociągać za sobą uczestnictwo $\mathrm{w}$ tych samych znaczeniach czy praktykach. Koncept nowoplemion z kolei, choć w równym stopniu odbijający charakter współczesnego uspołecznienia, a jednocześnie podobnie wrażliwy na zmiany standardów estetycznych, zakłada jednak także wspólnotę praktyk i znaczeń, a nawet pewien możliwy rygoryzm $\mathrm{w}$ ich przestrzeganiu (Warde 1997: 184-185). I pomimo faktu, że - jak zaznacza to Maffesoli - współczesny trybalizm znaczony jest pojawianiem się i zanikaniem plemion, wydaje się, że kategoria nowoplemion stanowi jednak propozycję bardziej nośną socjologicznie, a w związku z tym przydatniejszą $\mathrm{w}$ badaniach nad społecznościami opartymi na podobnym smaku.

\section{WINO - RAZEM CZY OSOBNO?}

Podstawową kwestią, jaka domaga się wyjaśnienia jest ustalenie, jaki jest preferowany przez informatorów wzór konsumowania wina? Towarzyski i wśród ludzi czy kontemplacyjny i samotniczy, na wzór „pewnej formy liturgii" (Bourdieu 2005: 345)?

Uważam, że nie można wina odkryć samemu, tak bym powiedział. Coś takiego, że gdybyśmy mogli dzisiaj pojechać i odkrywać piękne bezkresne równiny jakieś czy lodowce Antarktydy, to jednak obecność drugiej osoby, niezależnie czy bliskiej, czy nawet osoby, z którą nie wiążą nas dobre relacje, powoduje, że nam jest przyjemniej doznawać i poznawać różne rzeczy. I tak samo jest z winem. Wino samo pite samemu nie pasuje mi (M/40/Gdańsk). 
Uważam, że byłoby czymś bardzo ubogim i niepełnym, gdyby skupić się tylko na tym takim indywidualnym, samotnym wymiarze picia wina. Wino to jest życie, a życie domaga się dzielenia tego życia, tego fenomenu z innymi osobami. Oni muszą być w tym obecni (M/36/Gdańsk).

Nie pije się wina po to, żeby zapomnieć o świecie zewnętrznym, raczej tylko żeby po prostu było sympatyczniej, miło. To jest trochę tak jak kawa, spotykasz się na kawę, albo spotykasz się np. wieczorem, no to wtedy wino.. Tak że wydaje mi się, że wino pasuje właśnie do spotkań z ludźmi jak najbardziej, ale które mają na celu raczej miłą taką, jowialną atmosferę wytworzyć niż po prostu upić się nim, tak powiem (M/36/Starogard).

Ja zwykle piję z żoną albo z córką i zięciem. Jak jest zięć to bardzo często razem pijemy [...] ja osobiście wolę pić wino w towarzystwie i to takim, w którym można o tym winie porozmawiać. To jest tak w moim przypadku, że ja o winie mogę mówić godzinami. Ale żeby rozmawiać trzeba mieć tego interlokutora, trzeba mieć tego adwersarza, który, który będzie rozmawiał. To nie znaczy, że on musi być znawcą, absolutnie nie [...]. Pijąc wino i rozmawiając z osobami, które wymieniłem, my się delektujemy tym winem i, nie powiem, wymieniamy poglądy (M/56/Gdańsk).

Nie ulega wątpliwości, że wino łączy z ludźmi. Sytuacja spożywania wina powinna, w zgodnej opinii badanych, mieć charakter kolektywny, a obecność wina spełniać rolę czynnika podkreślającego towarzyską atmosferę zgromadzenia. Napój nie tylko, że pasuje do spotkań z ludźmi, to dodatkowo zbliża uczestniczących w sytuacji jego smakowania:

Picie wina wśród innych ludzi daje coś innego. To jest coś jakby taka wspólna zabawa. [...] Wino jest dobrym pretekstem, żeby się spotkać, żeby pobyć ze sobą. [...] To jest jakby takie życie, jakiego w Polsce brakuje - cieszyć się, obcy ludzie ze sobą. Jak na przykład spotykam się z obcymi ludźmi pijąc wino, to oni nie są dla mnie obcy, bo ja czuję, że jesteśmy związani, choćby poprzez tę pasję. [...] Wino powoduje, ze jesteśmy z ludźmi, jesteśmy razem i to jest jakby taka najpiękniejsza rzecz w tym winie (M/50/Gdynia).

Różne mogą być socjologiczne przesłanki uczestniczenia innych osób w sytuacji konsumowania wina. Najkrócej mówiąc, obecność innych może przemawiać za nieformalną i jowialną atmosferą spotkania, ale może też tworzyć wspólnotę osób połączonych preferencjami konsumpcyjnymi, budując tym samym możliwość wspólnego doświadczania wina i komunikowania własnych wrażeń. Trunek może łączyć i naznaczać konsumentów wspólną pasją, a jak podpowiada Georg Simmel (2005), towarzyskość jest tą formą uspołecznienia, która stwarza najbardziej dogodne warunki do satysfakcjonującego wspólistnienia amatorów w ramach aktu stylizowanej konsumpcji. W centrum Simmlowskiej towarzyskości leży bowiem reguła wzajemności, w myśl której każdy uczestnik powinien zapewnić drugiemu 
człowiekowi możliwie najwięcej korzyści towarzyskich, które byłyby równe wartościom otrzymanym (Simmel 2005: 36).

Zagadnienie społecznego wymiaru spożywania wina pociąga za sobą dalsze możliwe pytania - np. o jego miejsce i rolę $\mathrm{w}$ aranżowaniu towarzyskich zgromadzeń czy znaczenie wspólnych gustów dla formowania się (i utrzymywania) związków społecznych. Kwestie te, o znaczeniu pierwszorzędnym w kontekście tych rozważań, zostaną omówione w następnych podpunktach.

\section{INNI LUDZIE W WINIE - POŚREDNIO OBECNI, ALE (NIEKONIECZNIE) REALNI}

Rozpatrując problem poszukiwania społecznych więzi towarzyszących czy nabudowujących się na konsumowaniu wina/wokół relacji z winem, warto rozważyć możliwość, kiedy amatorzy doświadczają w trunku pośredniej obecności innych osób, takich których ślad odcisnął się w społecznej biografii określonej butelki. Wino staje się wówczas depozytariuszem tradycji, pokoleń wytwórców, przy czym ta więź ze społecznym kontekstem wytworzenia wina może mieć z perspektywy konsumenta zupełnie wyobrażony i nierzeczywisty charakter. Warto jednak przywołać taką możliwość, bo niezwykle trafnie wpisuje się ona w socjologiczne refleksje nad kulturą materialną. Tim Dant (2007: 14) podkreśla, że kontakt z przedmiotem wyraża przynależność społeczną jednostki, sam przedmiot zaś zastępuje innych ludzi w takiej quasi-społecznej relacji ze swoim użytkownikiem. Konsumowanie wina może zbliżać do innych osób, ale niekoniecznie wyłącznie $\mathrm{w}$ znaczeniu bezpośrednich kontaktów, ale - w sytuacji samotnej konsumpcji - może odsyłać do doświadczeń czy wspomnień związanych z sytuacjami, czy konkretnymi ludźmi, których ślad przewija się w smakowanym napoju.

Piję wina, bo to jest po prostu życie, to jest życie pokoleń przy produkcji tego wina, [...]. Po prostu uważam, że o ludziach należy wspominać. Jak chodzę na różne wycieczki po cmentarzach, to czytam. Tak samo pijąc takie wino, takie długowieczne w szczególności, ale też każde inne, ja po prostu wspominam ludzi, których nie znałem, ale którzy są mi teraz bliscy, bo są jakby z tą samą pasją (M/51/Gdynia).

Wino zbliża zatem do ludzi i, co ciekawe, nie tylko ku tym żyjącym realnie i dzielącym z amatorami "tu i teraz", ale także z tymi, których być może nigdy nie było, ale pojawiają się $\mathrm{w}$ świadomości i doświadczeniu konsumentów jako postaci do życia przywołane przez możliwy silny komponent emocjonalny i symboliczny, który cechuje akt konsumpcji. Można nawet 
zasadnie założyć, że zdolność trunku do przywoływania jakiejś postaci czy związanej z nią historii będzie coraz chętniej poszukiwaną przez amatorów właściwością tego napoju (Resnick 2008: 47).

Wino daje mi taką przygodę. To jest rodzaj takiego oderwania się od tej sfery codzienności, wejścia w taką inną formę jakby egzystencji, daje mi poczucie estetyki, poczucie swobody [...] w takim samotnym piciu wina wręcz jest taki czynnik przyjacielski, takiego nawet braku poczucia samotności $\mathrm{w}$ tym momencie...gdzieś się przebywa.... Takie poczucie, że nie jestem sama (K/43/Gdańsk).

Według ustaleń badaczy kultury materialnej, przedmioty naznaczone są obecnością innych osób, a $\mathrm{w}$ relacjach $\mathrm{z}$ nimi uaktywnia się komponent ludzki - ślad jednostek, które uczestniczyły w wykoncypowaniu i wytworzeniu dobra czy mówiąc inaczej „zapisana w przedmiotach pewna historia interakcji, która doprowadziła do ich powstania" (Krajewski 2008: 148). W ujęciu Danta $(2000 ; 2006)$ interakcja między użytkownikiem a rzeczą (interakcja materialna) odbywa się niejako między ludźmi, bo poprzez rzecz odzywa się człowiek czy też grupa ludzi, która przedmiot wykoncypowała i powołała do życia.

Być może takie wina, w których widać też innych ludzi, są bardziej bliskie, trudniej jest o nich zapomnieć. Czy są lepsze? Może stają się takie bardziej oswojone trochę, tak się trochę znosi granica między człowiekiem, konsumentem, a jednak winem jako pewną rzeczą materialną. [...]. Może być takie bardziej serdeczne, spersonifikowane. Wino, które ma twarz sprzedawcy, taką szczerą twarz sprzedawcy... np. z Montalcino... pamiętam takie wina właśnie. I będę je wspominał, bo mam wrażenie, że kupuję wtedy taką osobę przypiętą do butelki. [...] I to nie chodzi, że to wino musi być bardzo dobre czy wybitne w smaku, ale poprzez sam fakt obecności tych innych osób ono może być inne, w sensie bogatsze, że jeszcze za nim idzie coś dodatkowego, czy to będzie ślad jakiejś osoby, właśnie spojrzenie czyjeś, w którym widać taką szczerość wina (M/36/Gdańsk).

Zagadnienie obecności ludzi w konkretnym przedmiocie stanowi bardzo interesujący problem, który z pewnością warto pogłębić $\mathrm{w}$ dalszych badaniach. Dotyczy wszak jednego z centralnych zagadnień socjologicznych rozważań nad kulturą materialną - na ile rzeczy przemawiają słowami osób, które przewinęły się w różny sposób w toku ich społecznego żywota? Czy inaczej - na ile ludzki jest świat przedmiotów? W przypadku każdej rzeczy można mówić o zróżnicowanych postaciach i poziomach, w których pojawiać się może człowiek. Butelka wina nosi znamiona np. swojego autora (winiarza/producenta), ale też sprzedawcy - zarówno z lokalnej enoteki bliskiej miejscu wytworzenia napoju czy osiedlowego sklepu, zwłaszcza jeśli zakup poprzedzony jest rozmową i wymianą opinii, jak i osoby, z którą wiążą się wspomnienia związane ze spożywaniem określonej butelki. 


\section{WINO JAKO KONSERWANT DOTYCHCZASOWYCH (BLISKICH) RELACJI}

Wspólne konsumowanie wina może stanowić dodatkową okoliczność wzmacniającą istniejące relacje - czy to $\mathrm{w}$ ramach przyjaciól, znajomych, małżonków czy partnerów. W sytuacji kontaktu z bliską osobą, radość $\mathrm{z}$ wina może zostać dodatkowo podkreślona cieszeniem się drugą osobą. Trunek staje się zatem dodatkowym czynnikiem ułatwiającym bliskość między ludźmi oraz czerpanie z takiej sytuacji przyjemności.

To nie tak, że w każdym momencie można było takie wino otworzyć i wypić. To było wtedy, kiedy człowiek był spokojny i mogliśmy się cieszyć nie tylko tym winem, ale i sobą. Po prostu siedząc, będąc ze sobą (M/50/Gdynia).

Obecność drugiej bliskiej osoby może być warunkiem koniecznym do otwarcia butelki wina, jak i elementem sprzyjającym integracji rodziny:

Jest taka zasada, że jak jestem sam i wiem, że wieczorem nikt nie wróci, to nigdy nie otworzę butelki. Jeżeli np. żona poszła gdzieś na imprezę i wiem, że wróci i dopije ze mną do końca, to mogę sobie pozwolić na otworzenie i napicie się lampki i potem poczekanie z tą butelka na nią, ale sam tego tak nie zrobię, żeby sam wypić i je zdegustować. Jakoś też uważam, że degustacja wina wymaga rozmowy, wymaga rozmowy o winie nawet - a jak to czujesz, czy pasuje ci, czy nie pasuje, a czy fajne, czy warte powtórzenia? To jest potrzebne (M/40/Gdańsk).

Wino bywa także pieczęcią utwierdzającą relację między dwojgiem ludzi wspólnie spożywających trunek (a wcześniej razem uczestniczących w wydarzeniach związanych z jego zakupem). Jest ono zatem środkiem budowania i utwierdzania bliskości między ludźmi, staje się medium wspólnoty między osobami, łącząc zgodne smaki i tożsame doświadczenia. Dodatkowo ciekawe $\mathrm{w}$ poniższej relacji badanej jest niemalże spersonifikowanie trunku, które urasta do rangi dodatkowego uczestnika, skupiającego uwagę pary, prowokującego do wzajemnych kontaktów i wyposażającego je $\mathrm{w}$ dodatkowe znaczenie.

Czasami ważna jest osoba, z którą się pije, z którą się docenia ten smak i z którą się przeżyło też daną przygodę...to niekoniecznie musi być takie samotne picie, ale też właśnie druga osoba, ta, z którą się tych poszukiwań dokonywało. [...] Wtedy ważne jest spędzanie czasu razem. I taka komunikacja, bo w tym miejscu razem byliśmy, w tym miejscu razem wybieraliśmy to wino, mamy jednakowe czy podobne gusta, które jesteśmy w stanie jakoś wymienić między sobą [...]. I też taka wymiana, wymiana informacji na temat tego wina, to jest jak dzielenie się drugą osobą... Ja cały czas uosabiam wino jako kolejną osobę między dwojgiem ludzi (K/43/Gd). 
Zainteresowanie winem może stanowić także dodatkowy łącznik między bliskimi znajomymi, działając jako pretekst do wzajemnych kontaktów i odwiedzin:

Jak nie chodzę na degustacje, to staram się sobie jakoś sam...najczęściej to z $\mathrm{S}$. [z przyjacielem z pracy - PW], bo akurat on też pije dużo wina, więc z nim się jakoś tam spotykam i wtedy otwieramy jakąś nową butelkę. [...]_Spotykamy się, [...], ale oczywiście temu towarzyszy wino. To jest jakby tożsame, że spotykamy się i mamy na przykład jakiś pomysł na określoną potrawę. Będziemy jeść np. barana. No i do barana jakieś tam wino dobieramy. Oprócz tego wypijamy jakieś jedno wino wcześniej. [...] Fajne to jest, fajne. I wtedy też można spróbować nowych win (M/25/Gdańsk).

Możliwy wpływ wina na kształtowanie relacji ze znajomymi z pewnością jest zróżnicowany. Napój może stanowić jedynie dodatek do towarzyskiego spotkania i nie zmieniać istotnie charakteru społecznej sytuacji.

Są jeszcze przyjaciele [z którymi piję wino - PW] czyli grono, gdzie spotykamy się w domu. Przyjaciele - mam tu na myśli moich serdecznych kolegów, męskie towarzystwo. Pijemy czerwone wino półwytrawne, wytrawne, nie przywiązując żadnej wagi co do marki albo rocznika. Jest to wino w odpowiednim towarzystwie. [...] Towarzystwo jest jak najbardziej najważniejsze. Wino jest dodatkiem (M/37/Gdańsk)

W kolejnej wypowiedzi badanego zauważalny z kolei staje się nacisk na większą rolę wina $\mathrm{w}$ definiowaniu charakteru spotkania ze znajomymi. Zainteresowanie trunkiem jest już postrzegane jako środek budowania kolektywnej tożsamości.

[Wspólne picie wina - PW] będzie miało ten dodatkowy walor, że będzie dzielone wśród innych ludzi, że będzie czymś wspólnie przeżywanym, że będzie takim fajnym doświadczeniem, w którym spotykamy się i lubimy, a to wino staje się takim zwornikiem między nami. To przeżywane wino, które razem pijemy i o którym mówimy. [...] Spotykamy się po to, żeby pić wino, ale spotykamy się też po to, żeby o tym winie pogadać. Oczywiście cały czas jesteśmy dobrymi znajomymi, być może nawet jesteśmy przyjaciółmi, ale próbujemy dopuścić jeszcze wino jako ten dodatkowy element wiążący nas, ten dodatkowy element, który nas spaja jako grupę znajomych, którzy chcą ze sobą spędzać czas. Przy winie jakby, dzięki temu winu jeszcze bardziej intensywnie, jeszcze bardziej się spajając (M/36/Gdańsk)

Wino może też budować całe niepowtarzalne scenerie sytuacyjne, które stają się udziałem związanych ze sobą (i z winem) osób. Trunek ten nie odgrywa pierwszoplanowej roli, pozostaje raczej jednym z rekwizytów:

Lubię pić wino z moją ukochaną, jest to po prostu takie wniebowzięcie, [...] mnie to wprawia w taką wolność - siedzimy sobie gdzieś tam w fajnym miejscu i możemy 
się napić z butelki. Zdarzyło mi się przeżyć taką ciekawą historię na południu Niemiec, niedaleko gdzie wypływa Dunaj [...]. W takim uroczym zamku pod gruszą, wyobraź sobie. Obok wypływało jakieś źródełko, studnia. Ja z moją ukochaną mieliśmy sery różne i bagietkę. Popijaliśmy to dobrym, jakimś południowoniemieckim winem i byliśmy zachwyceni. Był upał, w środku zamku był lekki chłodek pod tą gruszą, a my piliśmy zimne dobre wino z butelki. To było coś niesamowitego, wakacje marzeń. Jak sobie przypominamy, oglądamy zdjęcia, to ja sobie przypominam smak tego wina! (M/37/Gdańsk)

Trunek może zatem wiązać ludzi poprzez wplecenie się w całą zaaranżowaną sytuację. Tym, co spaja parę ludzi jest nie tylko wino, ale kompleks czynników, w których odgrywa ono istotną rolę. Dodatkowo, co szczególnie widoczne $\mathrm{w}$ tej wypowiedzi informatora, to fakt nieco przewrotnego picia z butelki, które pobrzmiewa jak dysonans w atrakcyjnie zaaranżowanej całości. Ten gest jest raczej w kontrolowany sposób nieuładzonym incydentem, paradoksalnie utwierdzając dodatkowo kontrolowany i (jednak) cywilizowany charakter całej sytuacji.

\section{WSPÓLNOTY SMAKU, NOWOPLEMIONA I WINO - TOWARZYSKOŚĆ WINA I JEJ PRZEJAWY}

Dotychczasowa lektura wypowiedzi osób biorących udział w badaniu pozwala zapewne na stwierdzenie, że wspólne spotkania amatorów wina mogą rozgrywać się dwutorowo. Trunek może stanowić tło dla spotkania:

Ja uważam, ze fajnie by było, żeby były grupy, które są w stanie spotykać się właśnie degustując wina i rozmawiając o tematach takich ogólno życiowo-ludzkopolityczno-śmiesznych (M/40/Gd).

Może także być jego głównym motywem. W każdym jednakże przypadku wino bynajmniej nie umniejsza roli osób uczestniczących. Przeciwnie, niezależnie od okoliczności, obecność współbiesiadników wydaje się - z różnych względów - istotna.

Na pierwszej degustacji7 zaczęła jakby druga część picia wina - picie razem, nie tyl-

ko ja z żoną, bo to jakby naturalne jest, ale picie ludzi, którzy są obcy, ale jednocześ-

${ }^{7}$ Badany w swojej wypowiedzi odnosi się do niewielkich liczebnie (ok. 14-15 osób) degustacji organizowanych cyklicznie (średnio raz w miesiącu) przez francuską winiarnię w Sopocie. W tekście przyjmuję jednakże szerokie rozumienie degustacji jako okazji do testowania i smakowania wina, a zatem formy niewątpliwej rozrywki dla amatorów trunku. Nie musi być to możliwość stwarzana wyłącznie przez wyspecjalizowane sklepy winiarskie czy kluby miłośników, ale i samodzielnie planowana oraz organizowana przez zainteresowanych w ich domach (por. Falco 2006: 149-150). 
nie stają się bliscy, bo są razem z nami, uczestniczą w czymś. Na degustacji człowiek czerpie jakby radość wielotorowo - wino, atmosfera, towarzystwo, dzielenie się uwagami i słuchanie innych uwag. To jest to, przy czym się pięknie czas spędza. Wino nie pozwala na kłótnie, nie pozwala na pośpiech. Chodzi mi o to, że na degustacji uczestniczę jakby w takim pięknym spotkaniu [...] cieszymy się, jesteśmy razem, uczestniczymy w czymś fajnym, pięknym, miłym i spokojnie po prostu (M/50/Gdynia).

Moment wspólnego spożywania napoju z innymi osobami jest w wypowiedziach badanych szczególnym wydarzeniem. Jest to okazja do dzielenia się własną fascynacją z innymi uczestnikami, których obecność uruchamia dodatkowe możliwości czerpania satysfakcji. Niewątpliwie jest to także sposobność do komunikowania własnych preferencji estetycznych, rejestrowania komunikatów ze strony innych współbiesiadników, jak również ewentualne poszukiwanie potwierdzenia dla słuszności własnych aktów sądzenia. W wypowiedzi badanego wyraźnie zaznacza się estetyczny aspekt społecznej sytuacji degustowania wina, innymi słowy: „piękno form społecznych" (Gronow 1997; de la Fuente 2008, 2009). Spotkanie z trunkiem wśród obcych (ale bliskich przez fakt uczestniczenia we wspólnej praktyce jego smakowania) okazuje się pięknym spotkaniem, w toku którego uczestnicy zgodnie dostrajają własne wrażenia $w$ harmonijną całość. W ramach zgromadzenia dokonuje się znacząca przemiana: nieznani sobie ludzie stają się sobie bliscy przez fakt udziału we wspólnej pasji, ale i podzielania podobnych standardów gustu. Okazują się wspólnotą smaku (Gronow 1997), a w sytuacji wskazywanej powyżej być może nawet „estetyczną wspólnotą" (Lash 2009), jako że uczestniczą we wspólnych praktykach i zgadzają się co do znaczeń tych działań. Niewątpliwie wspólnotowość takiej społecznej formy ma charakter, by powiedzieć za Maffesolim (2008: 116-117), mgławicowy - zbiorowość pojawia się, znika i odtwarza w ramach kolejnych okazji wspólnej konsumpcji, w rytm zmiennych standardów konsumpcyjnych (Gronow 1997: 171).

To też jest fajne w degustacjach, że pijesz to z ludźmi, których niekoniecznie znasz, ale można poznać tych ludzi, można też wymienić się opiniami, polecić sobie nowe wina. Pewnie, pewnie. Ja nie lubię pić alkoholu samemu, nie robię tego chyba nigdy. Więc wino tak, z ludźmi. Tylko (M/25/Gdańsk).

Spotkania amatorów wina, takie wyspecjalizowane do samego smakowania są potrzebne, bo zwykłe spotkania przy trunku - np. takie wspominane $\mathrm{w}$ poprzednim podpunkcie, w kręgu znajomych - nie muszą tworzyć odpowiedniej atmosfery do celebrowania wspólnych preferencji konsumpcyjnych: 
Ja sam chciałem robić takie spotkania [z winem w roli głównej - PW]. [...] Jak zapraszam ludzi na imprezę, to to wszystko się rozlewa na zasadzie: bierz Tadziu pij, bo dzieci biegają. I nie ma takiego skupienia. Ja nie mówię, że to musi kosztować, nawet mogę te wina sam wyłożyć, ale w Trójmieście brakuje takiego miejsca, gdzie [...] można się zamknąć, zaprosić 10 osób - i my sobie tu pijemy w miłym otoczeniu. Oczywiście uiszczając jakieś opłaty właściwe. [...]. Brakuje takich miejsc i ja uważam, że taki klub jest fajnym sposobem.

Grupa miłośników wina może czerpać przyjemność ze zgromadzeń wyłącznie w celach jego poznawania i smakowania, otwarcie wykluczając możliwości innych kontaktów niż te oparte na wspólnych degustacjach. Takie wyspecjalizowane tematycznie relacje mają pozostać ograniczone jedynie do wspólnej konsumpcji:

Chciałbym znaleźć towarzystwo, z którym bym się spotykał czasami, ale ja się po prostu boję, że takie towarzystwo może chcieć być towarzystwem moim. A ja bym chciał towarzystwo tylko do wina. Bo po prostu nie jestem w stanie mieć za dużo znajomych, bo trzeba się z nimi spotykać, a nie ma się tyle czasu. Zresztą nie potrzeba aż tylu znajomych. Ma się bardzo bliskich przyjaciół, ma się zwykłych, okazjonalnych. I mnie by interesowało właśnie takie spotykanie się przy winie. [...] W takim towarzystwie, jak się razem będzie piło, to i wino będzie lepiej smakować. [...] Taka degustacja prywatna, nazwijmy to, byśmy mogli wybierać po prostu, umawiać się, że raz jeden, raz drugi wybiera, reszta zwraca pieniądze lub no po prostu każdy jakby raz na miesiąc, dwa organizuje coś takiego, kupuje butelkę wina. Cztery-pięć osób. Posiedzimy kilka godzin, coś przekąsimy, wypijemy, porozmawiamy na ten temat (M/50/Gdynia).

Wino wyłania się zatem jako główny pretekst dla zawiązywania społecznych relacji. Informatorzy wskazują na możliwą istotną zmianę w jego znaczeniu pod kątem tworzenia społecznych więzi - spożywanie trunku we wcześniejszych przypadkach raczej nie pretendujące do pierwszego rzędu aktorów społecznego spektaklu, teraz awansuje do ról pierwszoplanowych. Wychodzi z tła towarzyszącego spotkaniom towarzyskim $\mathrm{w}$ ramach kręgów znajomych, stając się głównym czynnikiem i zasadniczym kryterium nawiązywania nowych znajomości.

Wino może tworzyć zupełnie nowe znajomości, których bez wina nie udałoby się zawrzeć [...] wtedy wino działa jako taki mechanizm zbliżający ludzi w takim czystym sensie [...] Czyli zainteresowanie winem będzie powodowało, że ludzie będą się ze sobą jakoś kontaktować, wiązać. [...] To mogą być relacje takie doraźne, takie motywowane wolą spotkania się, wypicia i skomentowania jakiejś butelki czy jakichś butelek. Taki jakby tematyczny panel degustacyjny z takimi znajomymi doraźnymi, którzy chcą się spotykać, żeby razem pić, razem organizować degustacje. [...] I to byłoby niezmiernie fajne, gdyby takie znajomości też się tworzyły i takie degustacje odbywały. I to byliby właśnie tacy znajomi doraźni. Taka grupa do wina (M/36/Gdańsk). 
Podzielane kryteria gustu $\mathrm{w}$ takim samym stopniu działają jako znak wspólnoty na bazie uczestnictwa w zbliżonym kręgu preferencji estetycznych, jak i służą odgradzaniu się od innych, którzy takich standardów nie podzielają. Konsumowanie innego rodzaju napojów alkoholowych wiąże się z innym wzorem konsumpcji, a tym samym - z brakiem przynależności do grupy.

U nas w przypadku imprezy czy spotkania towarzystwa, praktycznie nie zdarza się, żeby ktoś przyniósł alkohol inny niż wino, jeżeli już przynosi, to jest jakiś taki bardziej obcy i chce pić coś innego. [...] Nikt z naszych znajomych nie pije whisky czy wódki. Jeżeli ktoś piwo chce, no to powiedzmy, bo to jest typowy napój letni [...]. (M/50/Gdańsk).

Elementarna umiejętność posługiwania się winem oraz przede wszystkim - zainteresowanie trunkiem okazują się jednym z ważnych kryteriów formowania kręgu znajomych. W takich przypadkach napój nie stanowi milczącego tła dla towarzyskiego spotkania, ale przejmuje aktywną rolę czynnika decydującego o udziale określonych osób w zgromadzeniu. Trunek staje się coraz wyraźniejszym znakiem potencjalnej wspólnoty zainteresowań między amatorami, a w konsekwencji również - indeksem odróżniania się czy wykluczania tych, którzy pasji nie podzielają. Fakt wzrastającego znaczenia wspólnego gustu jako elementu określającego charakter społecznych relacji nie ulega wątpliwości.

Kilka razy robiliśmy takie wieczory winne, na które zapraszaliśmy bliskich znajomych, ale też posługując się takim kryterium: czy ktoś pije wino? To nie byli wszyscy znajomi, wszyscy jak leci. Tacy, którzy nie są z winem związani na takie spotkania zapraszani nie byli. Oni byli jakby nie $\mathrm{z}$ tej bajki, tak bym powiedział. I w tym sensie fakt, że wino miało być spożywane filtrował trochę tych ludzi, dyktował, które osoby mają być zaproszone, które nie (M/36/Gdańsk).

Nawet wspólne zainteresowanie winem i podzielane standardy smaku nie oznaczają jednak automatycznie, że partner relacji będzie w stanie należycie docenić określoną butelką trunku, a zatem czy będzie traktowany jako równorzędny uczestnik grupy. Smak czy gust można bowiem rozumieć jako aktywność (Hennion 2008; Smith 2007), a w konsekwencji i umiejętność, którą należy odpowiednio trenować.

Ważne jest, żeby ten, który pije razem z nami, nam towarzyszy, żeby był na podobnym poziomie. To znaczy, ja nie poczęstuję dobrym winem osoby, która się nie zna na winach, ale nie dlatego, że żałuję pieniędzy, tylko uważam, że nie należy niczego marnotrawić [...]. Ktoś coś robi, ktoś się starał i należy to uszanować i dać osobie przygotowanej (M/50/Gdynia). 
Prezentowane w tym paragrafie warianty winnych spotkań, w dużym uproszczeniu, można zakwalifikować do dwóch rodzajów. W każdym przypadku różny będzie udział wina jako mechanizmu zakładającego czy uzasadniającego społeczne relacje.

Po pierwsze, będą bardziej zwrócone ku spożywaniu trunku i jego doświadczaniu. Napój będzie wówczas głównym bohaterem spotkania, treścią, która określa jego ostateczny sens. Mniejszą wagę ma wówczas familiarna czy nieformalna atmosfera spotkania. Byłoby jednak uproszczeniem założyć, że społeczne relacje $\mathrm{w}$ takim zdarzeniu nie mają znaczenia. Przeciwnie, wydaje się, że to właśnie $\mathrm{w}$ takich tematycznych, zdecydowanie nowoplemiennych w charakterze, czasowo zakładanych i terminowo obowiązujących relacjach, ważność społecznego otoczenia ma znaczenie szczególne. Ich waga wynika z uczestniczenia we wspólnym wydarzeniu, w którym odbijają się podzielane standardy smaku i przekonanie o ich istotności. Pozornie, w takim wzorze wspólnego konsumowania wina Simmlowskie reguły określające istotę towarzyskości znajdują słabsze potwierdzenie, jednakże to właśnie taka kontraktowa grupa amatorów trunku w znacznym stopniu ufundowana jest na regułach towarzyskiego obcowania: zarówno pod względem pewnej - ograniczonej do trwania samego aktu smakowania - jednorodności grupy (poprzez skupienie się na samym winie, czyli zawieszenie jednostkowych różnic jako nieistotnych dla sytuacji wspólnej konsumpcji), jak i maksymalizacji zasady wzajemności: wszyscy radujemy się winem oraz czerpiemy $\mathrm{z}$ tego przyjemność obserwując się nawzajem (Simmel 2005: 32-44). Sednem atmosfery towarzyskiej jest bowiem fakt powiązania uczestników w jedność, której doświadczanie stanowi kluczowy element doznawania indywidualnej przyjemności, która okazuje się w tym sensie funkcją satysfakcjonującego i aktywnego udziału współbiesiadników (Warde, Martens 2000: 208-209).

To jest wielka radość, cieszymy się smakiem, cieszymy się sobą i cieszymy się samym momentem tego połączenia wszystkich elementów: smaków, atmosfery, ludzi, wymiany myśli, niezwykłego nastroju, który staje się naszym wspólnym udziałem, kiedy się spotykamy, żeby się napić razem wina, chociaż właściwe byłoby powiedzenia bardziej: skosztować wina. [...] Chodzi o to, żeby się spotkać i wspólnie wino smakować. Wspólnie mówić o tym smaku i czerpać z tego radość (M/36/Gdańsk).

Po drugie, wino sprzyja luźnej, towarzyskiej atmosferze, w której nie ma statusu pierwszorzędnego uczestnika. Mogą zdarzać się jednak sytuacje, kiedy nieskrępowana atmosfera trafi na przeszkodę $w$ postaci np. takiej butelki trunku, która - ze względu na przekonanie o jej wysokiej jakości lub cenie - może onieśmielać uczestników, a tym samym wytrącać ich z luźnego trybu spotkania. Inaczej mówiąc, konieczne jest wspólne ustalenie cha- 
rakteru spotkania. Obowiązująca forma zgromadzenia, co typowe dla współczesnego trybalizmu, skłania uczestników do dopasowania się i zintegrowania. Jak podkreślają bowiem niektórzy autorzy, nowoplemiona mają świadomość własnych zasad i dość restrykcyjnie zmierzają do ich egzekwowania (Warde 1997: 184-185). Jest to z pewnością także konsekwencją reguł towarzyskiego współistnienia, zapewniających równe przyjemności wszystkim uczestnikom, a tym samym skłaniającymi ich do wzajemnego dopasowania się.

Degustacja ma coś takiego do siebie, że im są słabsze wina cenowo i jakościowo, tym degustacja jest bardziej towarzyska. Czyli spotykamy się, żeby się spotkać i przy okazji pijemy. Czym są lepsze wina, tym degustacja ma charakter skupienia się na winie i nie ma tzw. aspektu towarzyskiego. Nikt nie gada: a co tam, a jakiś kawał słyszeliście, a ten głupi z polityki... Nie ma takiej rozmowy. [...] Wino musi towarzyszyć spotkaniu jako rzecz dodatkowa, a nie jako jego rzecz główna. Spotykamy się, żeby popić zwykłe wina, np. zwykłą Hiszpanię w rozsądnych cenach. [...] I to jest fajne (M/41/Gdańsk).

W przypadku zgromadzeń opartych na konsumowaniu wina kwestią kluczową wydaje się ustalenie profilu, a zatem wypracowanie wspólnej płaszczyzny znaczeniowej dla takiego spotkania (wypracowanie definicji i przebiegu takiego spotkania). Jeśli definiować bowiem takie formy jako wspólnoty, to ich członkowie muszą spełniać warunek podzielania przekonań oraz uzgodnienia działań (Lash 2009). Nie zawsze jednak wszyscy uczestnicy takiej winiarskiej grupy będą zgodni co do założonego celu i charakteru spotkania. Bywa, że oczekiwania uczestników okazują się krzyżować ze sobą, a cierpi na tym towarzyska aura spotkania, które nie jest w stanie wypracować równych przyjemności wszystkim biorącym w nim udział.

Ktoś będzie się czuł niedowartościowany, że zaczynamy np. przy piątym winie gadać o pierdołach. Ktoś zakręci kieliszkiem i powie: no, trochę owocowe i wypije, a drugi kolega powie [...]: słuchajcie, nad nosem to się trzeba zastanowić cztery minuty. No i on tak kręci, a my mówimy: wiesz co, a w ustach taka beczkowa słodycz.... a on mówi: ale wy już przy ustach, a ja jeszcze cały czas kręcę... A kręć sobie, tak? A my zaczynamy rozmawiać o czymś innym i temat ucieka. [...] Czy mamy się spotykać dla wina, czy mamy się spotykać dla towarzystwa? (M/40/Gd) ${ }^{8}$

Niektórzy uczestnicy nastawieni są na poświęcenie się tematowi konsumowanych win: analizą i dyskusją nad ich zapachowo-smakowymi niuan-

8 Tytułem wyjaśnienia kilku użytych w wypowiedzi dość specjalistycznych określeń: "nos" - walory zapachowe wina; "usta" - właściwości smakowe; „kręcenie" dotyczy poruszania kieliszkiem z winem w celu zmaksymalizowania własności zapachowych trunku. 
sami czy porównywaniem z innymi butelkami. Takie zgromadzenie nie może spełnić swojej funkcji towarzyskiego spotkania, bo zakłócona pozostaje fundamentalna zasada towarzyskości: wzajemne dostosowanie się wszystkich uczestników, a w konsekwencji wspólne czerpanie równych satysfakcji z bycia ze sobą (Simmel 2005). Wyraźnie widać zatem, że społeczne sytuacje spożywania napoju powinny opierać się na ustalonej między uczestnikami formule: albo wyłącznie $\mathrm{z}$ winem w roli głównej, albo $\mathrm{z}$ winem $\mathrm{w}$ tle, $\mathrm{z}$ priorytetem dla luźnego towarzyskiego zgromadzenia, tak aby zagwarantować możliwą przestrzeń dla satysfakcji wszystkich uczestników zdarzenia. Najistotniejsze, aby uczestnicy każdej z możliwych sytuacji konsumpcji byli zgodni co do charakteru takiego towarzyskiego spotkania.

Mój kolega powiedział: nie ma degustacji, które nie mają tematu. [...] My degustujemy nie wino, ale jakieś wino. Mówi: ustalmy, [...] przynieś Toskanię, albo wina w rocznikach, nie wiem, Francja 2005. Przynosimy tylko to. Ja mam fachowców, którzy wybiegają w samo picie wina, oni nie chcą być na degustacji takiej rozbitej. Ja mówię o pewnej grupie ludzi, ja nie mówię, że wiążą mnie z nimi jakieś wielkie relacje, bo ja z nimi poza winem się specjalnie nie spotykam, ale oni starają się nadać winu jeszcze taki wyższy charakter, taki wyższy kierunek (M/41/Gdańsk).

Nie jest zamierzeniem tego tekstu, aby dokonać rozstrzygnięcia, w ramach której z opcji wyłaniających się z relacji badanych osób, zakodowany zostaje większy ładunek nowoplemienny. Wydaje się szczególnie ciekawe, że w opiniach amatorów wino pojawia się jako czynnik dodatkowy, który wpływa i modeluje istniejące relacje społeczne, w jakie uwikłani są badani, jak i - co socjologicznie niezmiernie interesujące - stanowi główny motyw zawiązywania ograniczonych co do zasięgu i przejściowych wspólnot smaku. Można jednakże całkiem zasadnie założyć, że szczególną przestrzenią dla manifestowania się towarzyskości będą wyspecjalizowane zgromadzenia zwrócone $\mathrm{w}$ dominującym stopniu ku praktykom wspólnej konsumpcji trunku. Zaznaczy się w nich bowiem specyficzny kod komunikacyjny integrujący uczestników, do którego wielką wagę przywiązywał Simmel (2005) - swoista etykieta określająca porządek sytuacji oraz regulująca wzajemne stosunki między uczestnikami. W spotkaniu amatorów etykieta przybierze postać kompleksu reguł stanowiących o kolejności spożywania win, sposobach ich podawania i konsumowania, doboru towarzyszących potraw czy wskazujących na właściwe kryteria oceniania trunków i wyrażania własnych opinii. Ten swoisty reżim decydujący o strukturze i temperaturze społecznej interakcji stanowiłby wyrazisty przejaw stylizacji, przekształcając tym samym akty spożywania wina w zaaranżowane formy społeczne właściwe np. posiłkowi. 


\section{PODSUMOWANIE}

Więziotwórczy charakter konsumowania wina można z pewnością rozpatrywać na kilka sposobów. Po pierwsze, trunek konserwuje i wzmacnia istniejące relacje społeczne. Staje się dodatkowym czynnikiem integrującym, a zarazem i polem do manifestowania podzielanych gustów estetycznych. Po drugie, okazuje się on prowokatorem czy katalizatorem nowych związków, które nie mogłyby się zdarzyć, gdyby nie udział i pośrednictwo wina oraz zainteresowanie trunkiem wspólne osobom uczestniczącym $\mathrm{w}$ społecznym zdarzeniu. Jak widać, w obu przypadkach podobieństwo gustów odgrywa zasadniczą rolę. Co oczywiste, wyspecjalizowane i typowo nowoplemienne związki traktują zainteresowanie i zaangażowanie w wino jako swój czynnik konstytutywny, jednak jest pewną niespodzianką, że tradycyjne (dotychczasowe) relacje społeczne $\mathrm{w}$ zauważalnym stopniu także mogą opierać się na podzielanych standardach smaku. Tym samym trunek może uaktywniać się jako dodatkowy czynnik utwierdzający relacje między znajomymi, doprowadzając nawet do modyfikowania ich charakteru czy intensywności, a nawet filtrowania kontaktów pod kątem spełniania przez nie warunku podobieństwa preferencji konsumpcyjnych. Pozostawię otwartym pytanie, czy może znaczyć to, że relacje między znajomymi, przyjaciółmi czy nawet być może członkami rodziny w coraz większym stopniu stają się określane przez czynniki estetyczne, zgodnie z wizją Maffesoliego, dla którego współczesne wzajemne więzi odzwierciedlać mają przede wszystkim zgodne preferencje estetyczne (Maffesoli 2008).

Biorąc pod uwagę relacje badanych osób, całkiem wyraźnie widać, że coraz większą rolę zaczyna współcześnie spełniać gust, który domaga się poszukiwania społecznych aren, na których mógłby być ćwiczony, doskonalony, konsultowany z innymi amatorami i wspólnie przeżywany. Wydaje się to trochę przeczyć Campbellowskiej tezie o zindywidualizowanym charakterze gustu, a w konsekwencji o skrajnie uprywatnionym charakterze samej konsumpcji (Campbell 1998; 2004; Drozdowski 2006: 202). Przeciwnie, analizując sylwetki wybranych amatorów wina, dostrzegalne jest ich konsekwentne dążenie (co najmniej na poziomie deklarowanych oczekiwań) do powiązania własnych poszukiwań konsumpcyjnych z akceptująca obecnością bliźnich o podobnych zapatrywaniach estetycznych. Smakowanie czy degustowanie wina wydaje się zatem mieć wiele wspólnego z tym, co Antoine Hennion (Hennion 2008; Hennion, Teil 2004) określił jako „wykonywanie smaku” (performing taste), które przekształca się tym samym w wyzwanie, mobilizujące do aktywności, a zarazem i mechanizm skłaniający ku relacjom z innymi. W rzeczywistości, w której w coraz większym 
stopniu zobowiązania etyczne między ludźmi wynikają z wspólnej estetycznej wrażliwości (Maffesoli 2008: 46), jednostkowy smak okazuje się polem do poszukiwań różnych form rezonansu społecznego, a w konsekwencji - środkiem testowania istniejących oraz zakładania nowych związków z ludźmi.

Jak poucza Maffesoli (2008: 117), rozpoznanie i socjologiczne zreferowanie dokonującego się współcześnie przejścia od społeczeństwa do dynamicznych i chaotycznych nowych form społecznych jest wyzwaniem trudnym, ale decydującym w kontekście dalszego rozwoju nauki o rzeczywistości społecznej. Socjologiczna refleksja nad nowymi formami uspołecznienia, jakie pociągać może za sobą pasja do wina i konsekwentne angażowanie się amatorów w praktyki konsumpcji (czyli nawiązywane i przeżywane przez amatorów relacje z winem) stanowi fragment większej całości, jaką jest specyfika współczesnych związków społecznych - zróżnicowanych, zmiennych, ukierunkowanych estetycznie i zorientowanych na wspólne formy przeżywania

W 51 zabaw (z) rzeczami Roger-Pol Droit (2005) w dowcipny sposób konstatuje fakt absolutnej zależności współczesnego człowieka od świata przedmiotów i zachęca w związku z tym do śledzenia - czy wręcz podglądania - trybów i okoliczności poprzez które przedmioty uaktywniają się między ludźmi. Rzeczy bowiem nie istnieją gdzieś poza ludzkim światem, ale właśnie w jego ramach, ciasno splecione ze swymi użytkownikami. Zadanie tropienia przedmiotów to zatem nie tyle ich prześwietlanie pod kątem znaczenia czy wypełnianych funkcji, ale przede wszystkim śledzenie zróżnicowanych i dynamicznych powiązań między rzeczami a aktorami wprawiającymi je w społeczny ruch oraz tegoż konsekwencjami. Warto pamiętać, jak słusznie punktuje Daniel Miller (2008), że więzi z rzeczami bynajmniej nie oddalają człowieka od świata innych ludzi, przeciwnie mogą podkreślać głębokie zażyłości między ludźmi i świadczyć o ich zakorzenieniu $\mathrm{w}$ wielu możliwych odsłonach społecznej rzeczywistości: rodziny, grupy przyjaciół czy nowoplemion.

Artykuł stanowił zatem - zawężoną do wybranego aspektu oraz przykrojoną do osobliwego przedmiotu: wina - próbę zastosowania się do sugestii Droita i odczytania wina w kategoriach jego właściwości grupowania ludzi wokół siebie. Biorąc pod uwagę różnorodność form, poprzez które wyrażają się w winie i poprzez wino inni ludzie, potrzeba wielu dociekliwych śledczych, aby namierzyć przypadki zjawiska, a w rezultacie rozjaśnić zawiły problem więziotwórczych potencji trunku. Społeczne znaczenie i oddziaływanie wina wciąż stanowi obszerne wyzwanie badawcze. 


\section{BIBLIOGRAFIA}

Barthes R. (2000), Mitologie, przeł. A. Dziadek, Warszawa: Wydawnictwo KR

Beck U., Giddens A., Scott L. (2009), Modernizacja refleksyjna. Polityka, tradycja i estetyka w porzadku społecznym nowoczesności, przeł. Jacek Konieczny, Warszawa: Wydawnictwo Naukowe PWN

Bennett A. (1999), Subcultures or neo-tribes? Rethinking the relationship between youth, style and musical taste, "Sociology" 33 (599)

Bourdieu P. (2005), Dystynkcja. Społeczna krytyka władzy sadzenia, przeł. Piotr Biłos, Warszawa: Scholar

Campbell C. (1998), Consumption and the rhetorics of need and want, "Journal of Design History", vol.11 (3) (s. 235-246)

Campbell C. (2004), I shop therefore I know that I am: the metaphysical basis for modern consumerism, [w:] K.M. Ekstrom, H. Brembeck (eds), Elusive consumption, Oxford: Berg (s. 27-44)

Charters S. (2006), Wine and society. Social and cultural context of a drink, London: Elsevier Butterworth-Heinemann

Colman T. (2008), Wine politics. How governments, environmentalists, mobsters and critics influence the wines we drink, Berkeley: University of California Press

Crane T. (2006), Wine as an aesthetic object, [w:] B.C. Smith (ed.), Questions of taste: philosophy of wine, Oxford: Oxford University Press (s. 141-155)

Dant T. (2005), Materiality and society, Maidenhead: Open University

Dant T. (2006), Material civilization: things and society, "British Journal of Sociology" 2006 vol $57 \mathrm{nr} 2$ (s. 289-308)

Dant T. (2007), Kultura materialna w rzeczywistości społecznej. Przekład zredagował i poprawił Janusz Barański, Kraków: Wydawnictwo UJ

Dant T. (2000), Consumption caught in the "cash nexus", "Sociology" 34 (s. 655-670)

Demossier M. (2004), Contemporary lifestyles: the case of wine, [w:] D. Sloan (ed.), Culinary taste. Consumer behaviour in the international restaurant sector, London: Elsevier Butterworth-Heinemann (s. 93-108)

Demossier M. (2005), Consuming wine in France: the 'wandering' drinker and the vin-anomie, [w:] T.M. Wilson (ed.), Drinking cultures: sites and practices in the production and expression of identity, Oxford: Berg Publishers (s. 129-154)

Demossier M. (2010), Wine drinking culture in France. National myth or a modern passion? Cardiff: University of Wales Press

Douglas M. (1987), A distinctive anthropological perspective, [w:] M. Douglas (ed.), Constructive drinking. Perspectives on drink from anthropology, Cambrigde and Paris: Cambridge University Press and Maison des Sciences de l'Homme (s. 3-15)

Douglas M., Isherwood B.C. (1996), The world of goods. Towards anthropology of consumption, London: Routledge

Droit R.P. (2005), 51 zabaw (z) rzeczami. Doświadczanie rzeczywistości, przeł. Elżbieta Urscheler, Gdańsk: Gdańskie Wydawnictwo Psychologiczne

Drozdowski R. (2006), Obraza na obrazy. Strategie społecznego oporu wobec obrazów dominujących, Poznań: Wydawnictwo Naukowe UAM

Elias N. (1990), Przemiany obyczajów w cywilizacji Zachodu, przeł. Tadeusz Zabłudowski, Warszawa: PIW

Falco C. (2006), Wino. Porady markiza z Grinon, przeł. Magdalena Dzięgielewska, Poznań: Zysk i S-ka 
de la Fuente E. (2008), The art of social forms and the social forms of art; the sociology-aesthetics nexus in Georg Simmel's thought, "Sociological Theory" vol 26 nr 4 (pp. 344-362)

de la Fuente E. (2009), On the promise of a sociological aesthetics: from Georg Simmel to Michel Maffesoli, dokument internetowy, www.aesculit.cn/article/2009/01/09/1042.html

Gronow J. (1997), The sociology of taste, London: Routledge

Hennion A. (2008), Those things that hold us together: taste and sociology "Cultural Sociology" vol 1(1), (s.97-114)

Komter A. (2001), Heirlooms, nikes and bribes: towards a sociology of things, "Sociology" vol 35 (1) (s.59-75)

van Krieken R. (1998), Norbert Elias, London and New York: Routledge

Miller D. (2008), The comfort of things, Cambridge: Polity

Krajewski M. (2008), Ludzie i przedmioty - relacje i motywy przewodnie, [w:] J. Kowalewski, W. Piasek, M. Śliwa (red.), Rzeczy i ludzie. Humanistyka wobec materialności, Olsztyn: Instytut Filozofii Uniwersytetu Warmińsko-Mazurskiego

Maffesoli M. (2008), Czas plemion. Schyłek indywidualizmu w społeczeństwach ponowoczesnych, przeł. Marta Bucholc, Warszawa: PWN

Mennell S. (2007), The American civilizing process, Cambridge: Polity

Resnick E. (2008), Wine trends. Success strategies for new markets, new consumers and new trends, New York: Palgrave Macmillan

Simmel G. (2005), Socjologia, przeł. Małgorzata Łukasiewicz, Warszawa: PWN

Simmel G. (2006), Socjologia positku, [w:] G. Simmel, Most i drzwi. Wybór esejów, przeł. Małgorzata Łukasiewicz (s. 272-282)

Smith B.C. (2007), The objectivity of taste and tasting, [w:] Barry C. Smith (ed.), Questions of taste. The philosophy of wine, Oxford: Oxford University Press (pp. 41-77)

Smith D. (2001), Norbert Elias and modern social theory, London: Sage

Teil G., Hennion A. (2004), Discovering quality or performing taste? A sociology of the amateur, [w:] M. Harvey, A. McMeekin, A. Warde (eds.), Qualities of food, Manchester: Manchester University Press (pp. 19-37)

Warde A. (1997), Consumption, food and taste. Culinary antinomies and commodity culture, London: Sage

Warde A., Martens L. (2000), Eating out: social differentiation, consumption and pleasure, Cambridge: Cambridge University Press

Watson M. (2008), The materials of consumption, "Journal of Consumer Culture" vol 8 (1), (s. 5-10)

Wilson T.M., (2001), Drinking cultures: sites and practices in the production and expression of identity, [w:] T.M. Wilson (ed.), Drinking cultures: alcohol and identity, Oxford: Berg Publishers (s. 1-24)

Woodward I. (2001), Domestic objects and the taste epiphany. Resource for consumption methodology, "Journal of Material Culture" vol 6 (2), (s. 115-136) 